\title{
Activity of Cytochrome P450 Monooxygenase (CYPs) Metabolic Enzymes as Markers of Insecticide Resistance in Anopheles vagus Muara Enim Mosquitoes,
}

\section{Indonesia}

\author{
Dalilah$^{1}$, Chairil Anwar ${ }^{*}$, Muhaimin Ramdja ${ }^{1}$, Dwi Handayani1, Lasbudi P Ambarita ${ }^{2}$, R. Irpan \\ Pahlepi $^{2}$, Ahmad Ghiffari ${ }^{3}$
}

${ }^{1}$ Department of Parasitology, Faculty of Medical Science, Universitas Sriwijaya. Indonesia.

${ }^{2}$ Research and Health Development Center, Ministry of Health, Baturaja, Indonesia.

${ }^{3}$ Department of Parasitology, Faculty of Medical Science, University of Muhammadiyah Palembang. Indonesia.

\author{
A R T I C L E I N F O \\ Keywords: \\ Pyrethroid synthetics \\ Resistance \\ Biochemical assay \\ Enzyme-linked Immunosorbent \\ Assay \\ Cytochrome P450 monooxygenase
} CYPs

*Corresponding author:

Chairil Anwar

E-mail address:

\section{chairil53@fk.unsri.ac.id}

All authors have reviewed and approved the final version of the manuscript.

https://doi.org/10.32539/bsm.v5i4.222

\begin{abstract}
A B S T R A C T
The use of synthetic pyrethroids in insecticide-treated bed nets (LLINs) and spray form (IRS) has been carried out since 2012 in Muara Emil Village and since 2016 in all villages in Tanjung Agung District, Muara Enim Regency. Biochemical resistance can occur to the enzymes that play a role in detoxifying the insecticide. This study aims to identify whether there is an increase in the levels of the enzyme Cytochrome P450 monooxygenase (CYPs) through the enzyme biochemical test on the malaria vector mosquito Anopheles vagus originating from Pagar Dewa Village and Muara Emil Village, Muara Enim Regency. The sample of female Anopheles mosquitoes was not full. Blood was taken at night using the resting collection method. Mosquitoes that have been identified as Anopheles vagus species are used to check CYPs enzyme levels using the ELISA method. The results of the biochemical test showed that enzyme levels increased from the Muara emil and Pagar Dewa village mosquitoes with a percentage of $71 \%$ and $61.53 \%$ (with cut off point OD> 0.165 ). The value of CYPs enzyme levels for mosquitoes from Muara Emil village was higher than that of the mosquitoes from Pagar Dewa Village (mean 0.005027 \pm 0.007 ). The increased activity of the CYPs enzyme plays a role in the detoxification of synthetic pyrethroid insecticides that can cause resistance. The high levels of enzymes from the villages of Muara Emil and Desa Farah Dewa are in line with intensive insecticide exposure in eradicating malaria vectors in the highest malaria transmission areas in Muara Enim Regency.
\end{abstract}

\section{Introduction}

Malaria is an endemic disease in South Sumatra. As many as 9 out of 17 districts in South Sumatra are still infected with malaria. In 2017, Muara Enim district occupied the highest number of suspected clinical malaria cases out of the nine malaria endemic districts. ${ }^{1}$ Vector control can be done physically or mechanically, using biotic, chemical agents, both for vectors and their breeding sites. ${ }^{2}$ WHO recommended efforts in vector control Chemically, malaria in the world using insecticides is Indoor Residual Spraying (IRS) house spraying and Long Lasting Insecticed Nets (LLINs) insecticides. Pyrethroids are the only insecticide used as an active ingredient in insecticide-treated bed nets. ${ }^{3}$ Pyrethroids are neurotoxins that act on voltage gated sodium channels by disrupting the central and peripheral nervous systems, causing weakness and death in mosquitoes. ${ }^{3,4}$ In theory, the mechanism of insecticide resistance can occur in one or more of the 
following ways: decreased penetration of the active insecticide through the skin, increased detoxification activity for example in the enzymes cytochrome P450 monoxygenase (CYPs) and carboxyl esterase and decreased target point sensitivity ${ }^{3}$.

The resistance of synthetic pyrethroid insecticides in mosquitoes has been widely reported. Especially in African, South American and Asian countries. Some of the reports of insecticide resistance to permethrin and DDT were detected in Anopheles gambiae by PCR. 5 Knock-down resistance $(\mathrm{kdr})$ mutations in Anopheles mosquitoes in South Lampung, Indonesia against pyrethroid insecticides are caused by mutations in the volt gate sodium channel (VGSC), gene point L1014F. 6 The kdr mutation was also found at point V1016G in the Aedes aegyptie mosquito in Palembang. ${ }^{7}$

Increased levels of metabolic enzymes may have a relationship with the resistance mechanism of the VGSC gene in the Anopheles stephensi mosquito from Afganisthan. ${ }^{8}$ However, certain synthetic pyrethroid gene resistance can be consistent with the expressed increase in the work of metabolic enzymes or on the contrary, the enzyme increase can occur without mutations in the VGSC gene or $k d r$. $^{9-12}$. The results that have not been in line between the increase in metabolic enzymes with mutations in the VGSC or $k d r$ genes have led to the identification of metabolic enzyme levels as markers of resistance which can be an important reference when molecular examinations have not found mutations. 5

\section{Methods}

\section{Study area}

The research locations are 3 districts / cities that meet the following criteria:

1. Obtained distribution of LLINs in the last 5 years.

2. There is a high density vector population of Anopheles sp.

Muara Enim District in Muara Emil Village and Fences of Dewa (356'38.1624 "LS / 10347'45.9774" East Longitude).
The research location is a malaria endemic area and in the last 5 years using insecticide-treated mosquito nets and IRS spraying and there is a high population density of Anopheles sp vectors, namely Pagar Agung village and Muara Emil village, Tanjung Agung district, Kab. Muara Enim

\section{Mosquito collection}

Mosquitoes were collected using the resting collection method. Adult female mosquitoes that are not full of blood, identified as Anopheles vagus species, were taken as samples, taken with ice boxes for further processing in the molecular laboratory of the Faculty of Medicine, Sriwijaya University.

\section{Biochemical test \\ Homogenization}

Mosquito samples were individually homogenized in $200 \mu \mathrm{l}$ phosphate buffer $(\mathrm{pH}$ 7.4) centrifuge at 4000 rpm then the mosquito homogenate samples were stored at $-85^{\circ} \mathrm{C}$ until the next stage of examination to prevent protein enzyme damage. 16 A total of $20 \mu 1$ aliquots of homogenate of each mosquito were included in the microplate well, then $80 \mu 1$ of phosphate buffer was added. Furthermore, in each well $200 \mu \mathrm{l}$ of TMB substrate and $253 \% \mathrm{H}_{2} \mathrm{O}_{2}$ solution were added. The microplate was incubated for 2 hours at room temperature. The color intensity produced in each well was measured for absorption using a microassay reader at a wavelength of $630 \mathrm{~nm}$. Cut off point, the Optical Density (OD) value for determining resistant mosquito samples was 0.165 .

\section{Results}

\section{Mosquito collection}

The number of mosquitoes obtained from the nighttime capture in the two villages was 704 female Anopeheles each, which were identified into seven species. In Muara Emil Village, 317 female Anopheles mosquitoes were found in three species.

From the results of catching mosquitoes from the two villages, the species were Anopheles vagus. This is 
in line with previous research by (didid, et al. 2017) and Budianto et al

\section{Biochemical test}

Biochemical ELISA test with the enzyme Cytocrome P450 Monooksigenase showed increased biochemical activity in mosquitoes originating from Muara emil and Pagar Dewa. Following are the results of the biochemical tests in Muara Emil and Pagar Dewa villages

The ELISA biochemical test showed an increase in the levels of the enzyme Cytocrome P450 Monooksigenase in mosquitoes from Muara Emil and Pagar Dewa villages. There was a difference in the mean levels of enzymes from the two villages, higher results were obtained for mosquitoes from Muara Emil village compared to Pagar Dewa village.

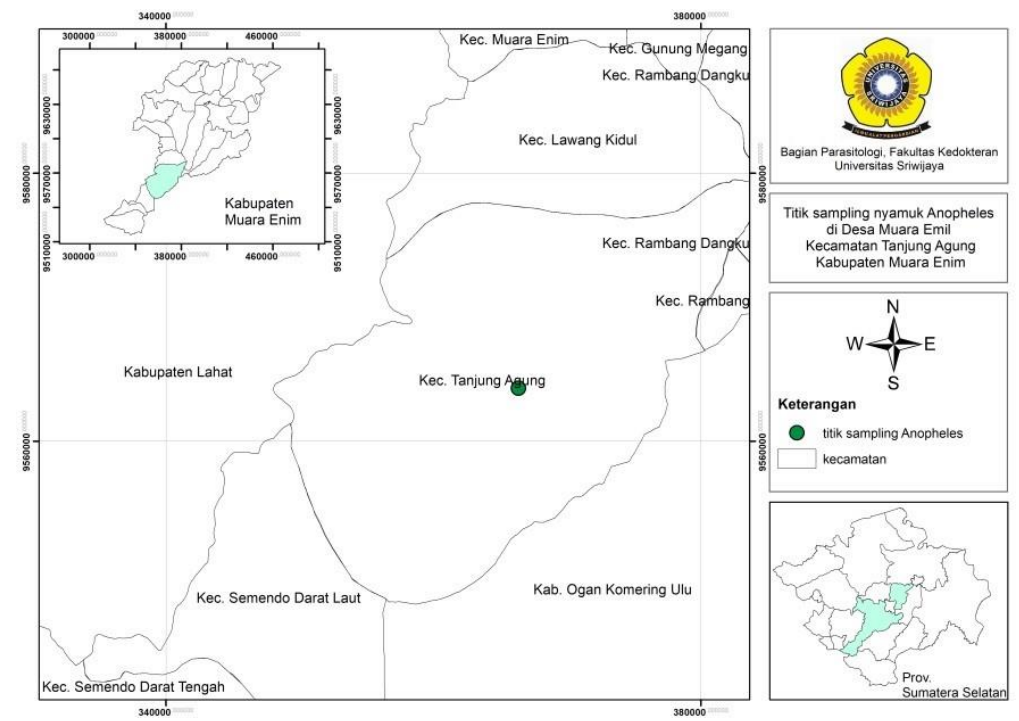

Figure Research sites

Table 1. Number of mosquitoes caught in Pagar Dewa village, Muara Enim

\begin{tabular}{clcc}
\hline No & Species & Total (tail) & $\%$ \\
\hline 1 & Anopheles vagus & 583 & 82.81 \\
\hline 2 & Anopheles kochi & 85 & 12.07 \\
\hline 3 & Anopheles nigerrimus & 4 & 0.57 \\
\hline 4 & Anopheles tesselatus & 9 & 1.28 \\
\hline 5 & Anopeheles sinensis & 3 & 0.43 \\
\hline 6 & Anopheles barbirostris & 8 & 1.14 \\
\hline 7 & Anopheles barbumbrosus & 12 & 1.70 \\
\hline & Total & 704 & 100 \\
\hline
\end{tabular}

Table 2. Number of mosquitoes caught in Muara Emil village, Muara Enim

\begin{tabular}{clcc}
\hline No & Species & Total (tail) & $\%$ \\
\hline 1 & Anopheles vagus & 314 & 99.05 \\
\hline 2 & Anopheles kochi & 2 & 0.63 \\
\hline 3 & Anopheles barbirostris & 1 & 0.32 \\
\hline & Total & 317 & \\
\hline
\end{tabular}


Table 3. Optical Density (OD) values of Anopheles vagus Mosquito Samples in Muara Emil Village

\begin{tabular}{ccccc}
\hline & 1 & 2 & 3 & 4 \\
\hline A & 0.787 & 0.359 & 0.525 & 1.139 \\
\hline B & 0.537 & 0.637 & 0.590 & 2.975 \\
\hline C & 0.791 & 0.668 & 0.549 & 0.783 \\
\hline D & 0.412 & 0.723 & 0.571 & 1.646 \\
\hline E & 0.752 & 0.513 & 0.551 & 0.680 \\
\hline F & 0.679 & 0.573 & 0.863 & 0.463 \\
\hline G & 0.637 & 0.569 & 0.843 & 0.038 \\
\hline H & 0.428 & 0.647 & 0.643 & 0.036
\end{tabular}

OD below 0.165 indicates that the sample is still vulnerable. The results in the table are 21 out of 30 mosquito samples from Muara Emil Village (70\%) showing OD levels above 0.165.

Table 4. Optical Density (OD) Value of Anopheles vagus Mosquito Samples in Pagar Desa Village

\begin{tabular}{ccccc}
\hline & 1 & 2 & 3 & 4 \\
\hline $\mathrm{A}$ & 0.334 & 0.972 & 1.160 & 1.220 \\
\hline $\mathrm{B}$ & 0.580 & 0.808 & 0.490 & 0.459 \\
\hline $\mathrm{C}$ & 0.674 & 0.567 & 1.870 & 0.431 \\
\hline $\mathrm{D}$ & 0.617 & 0.460 & 1.018 & 0.034 \\
\hline $\mathrm{E}$ & 0.865 & 0.537 & 0.896 & 0.035 \\
\hline $\mathrm{F}$ & 0.476 & 0.423 & 1.002 & 0.036 \\
\hline $\mathrm{G}$ & 0.612 & 0.786 & 0.502 & 0.037 \\
\hline $\mathrm{H}$ & 0.517 & 0.368 & 1.147 & 0.040 \\
\hline
\end{tabular}

OD below 0.165 indicates that the sample is still vulnerable. The results in the table show as many as 16 out of 26 samples from Pagar Dewa Village (61.53\%)

Table 5. OD values of cytochrome P450 enzymes by region

\begin{tabular}{ccccc}
\hline \multirow{2}{*}{ Mosqueto territory } & N & \multicolumn{2}{c}{ OD cytochrome P450 enzymes } \\
\cline { 3 - 5 } & & Average \pm Sd & Minimum & Maximum \\
\hline Muara Enim & 30 & $0.3543 \pm 0.482$ & 0.01 & 2.58 \\
Pagar Dewa & 26 & $0.3531 \pm 0.340$ & 0.02 & 1.47 \\
\hline
\end{tabular}

Table 6. Value of cytochrome P450 enzyme levels by region

\begin{tabular}{ccccc}
\hline \multirow{2}{*}{ Mosqueto territory } & \multirow{n}{*}{} & \multicolumn{2}{c}{ Cytochrome P450 enzyme levels } \\
\cline { 3 - 5 } & & Average \pm Sd & Minimum & Maximum \\
\hline Muara enim & 30 & $0.005027 \pm 0.007$ & 0.000 & 0.0373 \\
Pagar dewa & 26 & $0.004950 \pm 0.004$ & 0.0002 & 0.0212 \\
\hline
\end{tabular}




\section{Mosquito Collection}

The mosquitoes that dominate the night catches in Muara Emil and Pagar Dewa villages are Anopheles vagus mosquitoes with a percentage of $82 \%$ and $99 \%$. In a previous study in Muara Emil Village, the Anopheles vagus and Anopheles barbirostris mosquitoes were the dominant mosquitoes of capture. ${ }^{12}$ Although the Anopheles vagus mosquito is a mosquito that has a zoophilic tendency and likes livestock, an mosquito An has been reported. vagus is proven to bite humans all night both indoors and outdoors. ${ }^{13}$ Its dominant population and identification of plasmodium parasites in the mosquito's body, prove that this mosquito is a potential vector for the transmission of malaria.14-15 Apart from An. vagus, another species was found, namely An. There are quite a lot of Kochi in Muara Emil Village. Mosquito An. Kochi also has a zoophilic tendency and is known as the cage mosquito. Mosquito An. Kochi is a malaria vector mosquito in the Sulawesi area, although in South Sumatra there is no evidence of sporozoites being found in these mosquitoes, however, with a large enough population, they have the opportunity to become a vector. ${ }^{15-16}$

\section{Biochemical Test}

Cytocrome P450 Monooksigenase enzyme is an enzyme involved in the metabolic processes of various insect molecules. ${ }^{17}$ Most of the Cytocrome P450 Monooksigenase is involved in the detoxification process in the endoplasmic reticum and catalyzes the oxidation of xenobiotics or endogenous compounds in the presence of NADPH-cytochrome P450-reductase. ${ }^{18}$

Resistance can result from mutation of the targeted protein (target site resistance) low penetration rate or insecticide sequestration and increased insecticide degradation known as metabolic resistance ${ }^{19}$. Metabolic resistance is the most common mechanism. The resistant strains may have higher or more efficient enzyme action. Apart from being more efficient, these enzyme systems can also have a broad spectrum of activity, namely they can reduce the sensitivity of various insecticides. ${ }^{19,20}$ Insecticide resistance occurs from extensive long-term use. 5,19 There is an increase in the action of enzymes to mark the neutralization process of toxins, including pyrethroid synthetic insecticides in the mosquito's body. ${ }^{21}$

A wide variety of biochemical resistance findings in mosquitoes in the world. The resistance that occurs can stand alone or in conjunction with the target site resistance. It was found that increased activity of Cytocrome $\mathrm{P} 450$ and esterase enzymes in Aedes aegyptie mosquitoes was associated with exposure to pyrethroid deltamethrin and permethrin. ${ }^{22}$ Increased levels of metabolic enzymes were associated with the resistance mechanism of the target site of the VGSC gene $k d r$ in Anopheles stephensi mosquitoes from Afganisthan. in line with the expressed increase in metabolic enzyme action, such as in the study of the VGSC Aedes aegyptie gene in Malaysia, it was found that there was metabolic resistance without any evidence of resistance to the $k d r$ gene. ${ }^{10}$ This also applies to this study which has found elevated levels of the enzyme Cytocrome P450. Although enzyme levels have been found to increase, previous studies on mosquito samples from the same area had not found resistance to the VGSC gene. ${ }^{12}$

\section{Conclusion}

There has been an increase in the levels of the enzyme Cytocrome P450 monooksigenase in Anopheles vagus mosquitoes from Muara Emil and Pagar Dewa villages. The high levels of enzymes are in line with the intensive exposure to insecticides as a prevention of vector bites in the highest malaria transmission area in Muara Enim Regency.

Further studies are needed at the molecular level of the enzyme Cytocrome P450 monooxygenase genes (CYPs) to determine the expression of CYPs genes that trigger an increase in the action of these enzymes.

\section{References}

1. Health Office of South Sumatra Province, Current Situation of Malaria in South Sumatra 
2015 and 2016

2. Ministry of Health RI. 2010. Regulation of the Minister of Health of the Republic of Indonesia Number: 374 / MENKES / PER / III / 2010 concerning Integrated Vector Control.

3. WHO. 2017. Conditions for deployment of mosquito nets treated with a pyrethroid and piperonyl butoxide.

4. Silva, Anna, P.B., Joselita Maria M Santos, Ademir J Martins. 2014. Mutations ini Voltagegated Sodium Channel gene of Anopheliine and their association with resistance to pyrethroids - a review. Parasite and Vektors.Vol 7:450.

5. Yadouleton, A.W., Gil Padonou, Alex Asidi, Nicolas Moiroux, Sahabi Bio-Banganna, Vincent Corbel, Raphael N'guessan, Dina Gbenou, Imorou Yacoubou, Kinde Gazard, Martin C Akogbeto. 2010. Insecticide resistance status in Anopheles gambiae in southern Benin. Malaria Journal. Vol 9:83.

6. Syafruddin, D., Anggi ,P.N., Hidayati, Puji BS, Hawley A.W., Sukowati, S. Lobo, N.F. 2010. Detection of $1014 \mathrm{~F} \mathrm{kdr} \mathrm{mutation} \mathrm{in} \mathrm{four} \mathrm{major}$ Anopheline malaria vectors in Indonesia. Malaria Journal.Vol 9:315.

7. Ghiffari, A., Fatimi H., Anwar, C. 2013. Deteksi Resistensi Insektisida Sintetik Piretroid Pada Aedes Aegypti (L.) Strain Palembang Menggunakan Teknik Polymerase Chain Reaction. Jurnal Aspirator, Vol.5, No. 2, hal: 37-44

8. Safi,N.H.Z., Ahmadi A.A., Nahzat, S., Ziapour, S.P., Nikooka, S.H., Fazeli-Dinan, M., Enayati., A., and Hemingway., J. 2107. Evidence of metabolic mechanisms playing a role in multiple insecticides resistance in Anopheles stephensi populations from Afghanistan. Malaria Journal. Vol 16: 100.

9. Ishak, I. H., Jaal, Z., Ranson, H. \& Wondji, C. S. 2015. Contrasting patterns of insecticide resistance and knockdown resistance $(\mathrm{kdr})$ in the dengue vectors Aedes aegypti and Aedes albopictus from Malaysia. Parasit Vectors vol 8: 181 .
10. Ishak, I.H.,Jacob M. R., Sulaiman, S., Ibrahim.,Stott,R., Longbottom, J., Irving,H, \& Wondj,C.S. 2016. Cytochrome P450 gene CYP6P12 confers pyrethroid resistance in $\mathrm{kdr}-$ free Malaysian populations of the dengue vector Aedes albopictus. Scientificreports. Vol 6:24707.

11. C.hoovattanapakorn, N., Jintana Yanola, J., Lumjuan, N., Saingamsook, J., and Somboon, P. 2017. Characterization of metabolic detoxifying enzymes in an insecticide resistant strain of Aedes aegyptiharboring homozygous S989P and V1016G kdr mutations. Med. Entomol. Zool. Vol. 68 No. 1page: 19-26.

12. Haryanto,D., Dalilah., Anwar, C., Prasasti,G.D, Handayani,D., Ghiffari,A.,2018. Investigasi resistensi Anopheles sp. Terhadap insektisida piretroid dan kemungkinan terjadinya mutasi gen voltage gated sodium channel (VGSC). Indonesian Journal of Entomology. Vol. 15 No. 3, 134-142.

13. Hanafy I. 2015. Keanekaragaman jenis, kepadatan dan aktivitas mengisap darah Anopheles (Diptera: Culicidae) pada Aplikasi zooprofilaksis di daerah endemis malaria..

14. Budiyanto, Anif, 2016. Konfirmasi vektor malaria di Kabupaten Muara Enim Provinsi Sumatera Selatan tahun 2016. Jurnal Aspirator. Vol 9(2), hal 51-60.

15. Munif. 2009. Nyamuk vektor Malaria dan hubungannya dengan aktivitas kehidupan manusia di Indonesia. Jurnal Aspirator. Vol 1, No 2, halaman : 94-102.

16. Suwito., Hadi, U.K., Sigit , S.H., Sukowati, S. 2010. Hubungan iklim, kepadatan nyamuk Anopheles dan kejadian penyakit malaria. J Entomologi Indonesia. 2010;7(1):42-53.

17. Feyereisen R. Arthropod CYPomes illustrate the tempo and mode in $\mathrm{P} 450$ evolution. Biochim. 2011. Biophys. Acta. Vol 1814, page :19-28.

18. Murataliev M. B., Guzov V. M., Walker F. A., Feyereisen R. P450 reductase and cytochrome b5 interactions with cytochrome P450: effects 
on house fly CYP6A1 catalysis. 2008. Insect

Biochem. Mol. Biol. Vol 38, page :1008-1015.

19. Hemingway J, Hawkes NJ, McCarroll L, Ranson H. The molecular basis of insecticide resistance in mosquitoes. 2004. Insect Biochem Mol Biol. Vol 34(7), page:653-65.

20. Hemingway, J. and Ranson, H. (2000) Insecticide resistance in insect vectors of humandisease. Annu. Rev. Entomol.45, 371391.

21. David J. P., Mahmoud Ismail H., ChandorProust A., Paine M. J. I. Role of cytochrome $\mathrm{P} 450$ s in insecticide resistance: impact on the control of mosquito-borne diseases and use of insecticides on earth. Philos. Trans. R. Soc. London Ser. B. 2013;368:20120429

22. Rodriguez MM, Bisset JA, Fernandez D. 2007. Levels of insecticide resistance and resistance mechanisms in Aedes aegypti from some Latin American countries. J AmMosq Control Assoc.;23(4):420-9. 